\title{
Role of Complete Blood Picture in Predicting the Etiology of Extrahepatic Cholestasis
}

\author{
WAEL M. MORSY, M.Sc.*; ESAM A. EL-BEIH, M.D.** and MUHAMMAD A. EL-MASRY, M.D.*** \\ The Department of Internal Medicine, Al-Eman General Hospital* and Faculty of Medicine, \\ Assiut University Hospitals**,*** and Department of Tropical, Al-Rajhy Liver Hospital***
}

\begin{abstract}
Background: Extrahepatic cholestasis is a common problem worldwide and faced in daily practice however it's etiology has a wide range, before starting treatement it is mandatory to reach the cause of the disease. Investigative tools such as computerized tomography, magnetic resonance cholangiopancreatography etc are expensive, not available in every centers, moreover their accuracy not reaching $100 \%$.
\end{abstract}

Aim of Study: To analyse the role of complete blood count parameters namely RDW, MPV, PDW, PCT, N/L ratio, P/L ratio which are cheap and already available in 1ry care centers in assessment of extrahepatic cholestasis.

Patients and Methods: It is a cross-sectional comparative descriptive study conducted during a period of one year starting from 1/3/2016 to 28/2/2017 at Al-Rajhy Liver Hospital, Assiut University Hospitals, on patients presented with definitive evidence of extrahepatic cholestasis by clinical examination, laboratory evidence and trans-abdominal ultrasonography.

Results: Thirty eight patients having extrahepatic cholestasis were included in the final analysis with a mean age of 47 years of them 14 patients were male. And 10 cases were taken as a control group of them 6 cases were male. Comparing between different etiological types of extrahepatic cholestasis as regards six parameters of the complete blood pictures namely RDW, MPV, PDW, PCT, N/L ratio, $\mathrm{P} / \mathrm{L}$ ratio shows no significant differences between them. But MPV and PDW were significantly elevated in malignant distal group than control group.

Conclusion: Complete blood count parameters namely RDW, MPV, PDW, PCT, N/L ratio, P/L ratio have no significant role in the differentiation between different etiologies of extrahepatic cholestasis. But MPV and PDW were significantly elevated in malignant distal extrahepatic cholestasis than cases without hyperbilirubinemia.

Recommendation: Further studies on a larger patient's numbers is recommended.

Correspondence to: Dr. Wael M. Morsy, The Department of Internal Medicine, Al-Eman General Hospital
Key Words: Extrahepatic cholestasis - Complete blood count - Malignant-Calcular.

\section{Introduction}

EXTRAHEPATIC cholestasis results from biliary obstruction, which is blockage of any duct that carries bile from liver to gall bladder and then to small intestine [1], extrahepatic cholestasis is a complex syndrome with both benign etiology and malignant etiology, Gallstone disease is the most common, but at the same time the most benign form of extrahepatic cholestasis [2], Choledocholithiasis (CDL) is a troublesome component of biliary tract disease. Malignant biliary obstruction is defined as a cancer being responsible, for the mechanical blockage of the bile output [3]. Generally, the most common etiologies of malignant strictures include pancreatic adenocarcinoma or cholangiocarcinoma, although metastatic disease, ampullary neoplasia, gallbladder malignancy, hepatocellular carcinoma are all possibilities [4].

Ultrasound (US) is the imaging modality of choice for the initial screening of biliary disorders [5].

ERCP is considered as a gold standard for imaging of the biliary tract because of its high diagnostic accuracy [6].

Red blood cell distribution width (RDW) is a quantitative measure of anisocytosis [7], Red cell distribution width (RDW) is a routine component of Complete Blood Count (CBC) analysis, a relatively inexpensive tool and traditionally used in the differential diagnosis of anemia [8]

PVIs are a group of parameters derived from routine blood counts. MPV and PDW are the most 
validated representatives of PVIs. MPV and PDW are not only inexpensive but also universally available with blood routine measurements, which can be automatically calculated from PLT count by hematology analyzers. Mean platelet volume (MPV) and Platelet Distribution Width (PDW) are morphometric indices as well as quantitative measures of size distribution and variability of PLT, which can be called as Platelet Volume Index (PVI) collectively [9].

PCT is the arithmetic product of PLT count and PLT volume, which is positively correlated with PLT [10].

Blood Neutrophil to Lymphocyte (N/L) ratio is an easily accessible and reliable marker of subclinical inflammation that can be easily obtained from the differential white blood cell count [11,12]

The PLR combines the predictive risk of platelet and lymphocyte counts and is a new prognostic marker of inflammation [13].

The aim of the present study is to evaluate the role of complete blood count parameters namely RDW, MPV, PDW, PCT, N/L ratio, P/L ratio which are cheap and already available in 1ry care centers in assessment of extrahepatic cholestasis as a complementary method to diagnose challenging cases.

\section{Patients and Methods}

As part of a quality assurance programme, records from all patients admitted to Al-Rajhy Liver Hospital, Assiut University Hospitals were extracted if they met the inclusion criteria.

Inclusion criteria: Definitive evidence of exrtahepatic cholestasis by clinical examination, laboratory evidence and transabdominal ultrasonography has been considered in our study.

Exclusion criteria:

- Age less than 14 years.

- Previous ERCP, PTBD, biliopancreatic anastomosis.

- Recent blood transfusion within one month.

- Anaemia and haemoglobinopathies: Thalassaemia.

- Myeloproliferative disorders.

- Splenomegaly.

- Diabetes mellitus.

- Heart failure.
- Coronary artery disease.

- Renal disease.

- Thrombosis, pulmonary embolism and ischaemic cerebrovascular stroke.

- Malignancy outside hepatopancreatobiliary system.

- Tuberculosis.

- Bacteremia and septicemia.

Patients were subjected to careful history taking and thorough general and abdominal examination.

Once patients were admitted blood samples were collected using EDTA for CBC analysis using PENTRA or MICROS automated hematology analyzers.

Six CBC parameters used in the study four of them were obtained from the analyzer namely RDW, MPV, PCT and PDW the other two parameters namely Neutrophil-to-Lymphocyte Ratio (NLR) and Platelet-to-Lymphocyte Ratio (PLR) were calculated.

All patients were subjected to transabdominal ultrasonography.

The final diagnosis of the etiology of extrahepatic cholestasis is confirmed by either (1) Magnetic resonance cholangiopancreatography, (2) Computed tomography, (3) Endoscopic retrograde cholangio pancreatography or endoscopic ultrasonography, (4) Percutaneous transhepatic cholangiography, (5) Biopsy, or (6) Surgically.

Diagnostic and/or therapeutic ERCP was done for 72 cases, EUS was done for 5 cases, PTD was done for 4 cases, biopsy was taken from 5 cases.

Patients has been subdivided into five groups:

Group A1: Patients with proximal malignant extrahepatic cholestasis.

Group A2: Patients with distal malignant extrahepatic cholestasis.

Group B1: Patients with extrahepatic cholestasis due to a benign biliary stricture.

Group B2: Patients with extrahepatic cholestasis due to stones.

Group C: Control.

Statistical analysis:

SPSS program was used for statistical analysis. A $p$-value less than 0.05 was considered as statis- 
tically significant $(p<0.05)$ and a $p$-value less than 0.01 was considered highly statistically significant $(p<0.01)$.

Ethics informed oral or written consent was obtained from all patients, approval by the Local Ethics Committee to conduct and publicate the study.

There is no risk during application of the research, tools to assess the patients psychologically, confidentiality was maintained during all stages of the assessment.

\section{Results}

Initially 80 patients were selected, of them 25 cases have no sufficient data and 17 cases died before reaching the final etiologic diagnosis.

A total of 38 patients with extrahepatic cholestasis were included in the final analysis.

And 10 cases were taken as a control group which have no hyperbilirubinemia.

Table (1) display the demographic data and CBC indices, 20 patients were males, 28 patients were females, mean patient's age was 46 years with a range of 18-84 year. Mean RDW $12.47 \%$ with a range of 9.7-20.6\%, mean MPV $8.40 \mathrm{fl}$ with a range of $6.3-10.6 \mathrm{fl}$, mean PCT $24.33 \%$ with a range of $10.1-37.9 \%$, mean PDW $14.78 \%$ with a range of $8-21.3 \%$, mean NLR 2.89 with a range of $0.62-13.1$, mean PLR 169.29 with a range of 83.26323.28

Stone disease accounted for the majority of patients with extrahepatic cholestasis $(52.63 \%)$. The second most common cause was malignancy (28.94\%), benign stricture account for $18.43 \%$ see (Table 2).

As regard sex there is no differences between studied groups see Fig. (1) also there is no differ- ences between studied groups as regard age see Fig. (2).

In comparison between the five studied groups as regard six studied $\mathrm{CBC}$ parameters the analysis demonstrates that MPV and PDW were significantly elevated in malignant distal group in comparison to control group see (Tables 3A,B).

Table (1): Descriptive data.

\begin{tabular}{|c|c|}
\hline & No. \\
\hline \multicolumn{2}{|l|}{ Sex: } \\
\hline Male & 41.7 \\
\hline Female & 58.3 \\
\hline \multicolumn{2}{|l|}{ Age: } \\
\hline Range & $18-84$ \\
\hline Mean \pm SD & $46.88 \pm 15.29$ \\
\hline \multicolumn{2}{|c|}{ Red cell distribution width (RDW) \%: } \\
\hline Range & $9.7-20.6$ \\
\hline Mean \pm SD & $12.47 \pm 2.07$ \\
\hline \multicolumn{2}{|c|}{ Mean Platelet Volume (MPV): } \\
\hline Range & $6.3-10.6$ \\
\hline Mean \pm SD & $8.40 \pm 0.88$ \\
\hline \multicolumn{2}{|c|}{ Plateletcrit (PCT) \%: } \\
\hline Range & $10.1-37.9$ \\
\hline Mean \pm SD & $24.33 \pm 5.92$ \\
\hline \multicolumn{2}{|c|}{ Platelet Distribution Width $(P D W) \%$ : } \\
\hline Range & $8-21.3$ \\
\hline Mean \pm SD & $14.78 \pm 2.77$ \\
\hline \multicolumn{2}{|c|}{ Nutrophil/Lymphocyte Ratio (N/L Ratio): } \\
\hline Range & $0.62-13.1$ \\
\hline Mean \pm SD & $2.89 \pm 2.49$ \\
\hline \multicolumn{2}{|c|}{ Platelet/Lymphocyte Ratio (P/L Ratio): } \\
\hline Range & $83.26-323.28$ \\
\hline Mean \pm SD & $169.29 \pm 62.85$ \\
\hline
\end{tabular}

Table (2): Comparing between studied groups as regards demographic data.

\begin{tabular}{|c|c|c|c|c|c|c|c|c|c|c|}
\hline & \multicolumn{9}{|c|}{ Group } & \multirow{3}{*}{$\begin{array}{c}p- \\
\text { value }\end{array}$} \\
\hline & \multirow{2}{*}{$\frac{\text { Benign }}{\text { No. \% }}$} & \multicolumn{2}{|c|}{$\begin{array}{l}\text { Calcular } \\
\text { OJ }\end{array}$} & \multicolumn{2}{|c|}{$\begin{array}{l}\text { Malignant } \\
\text { distal }\end{array}$} & \multicolumn{2}{|c|}{$\begin{array}{l}\text { Malignant } \\
\text { proximal }\end{array}$} & \multicolumn{2}{|c|}{ Control } & \\
\hline & & No. & $\%$ & No. & $0 / 0$ & No. & $\%$ & No. & $\%$ & \\
\hline \multicolumn{11}{|l|}{ Sex: } \\
\hline Male & 228.6 & 6 & 30 & 4 & 66.7 & 2 & 40 & 6 & 60 & \\
\hline Female & 571.4 & 14 & 70 & 2 & 33.3 & 3 & 60 & 4 & 40 & 0.337 \\
\hline Age & $44 \pm 14.4$ & \multicolumn{2}{|c|}{$42.75 \pm 13.03$} & \multicolumn{2}{|c|}{$50.67 \pm 9.14$} & \multicolumn{2}{|c|}{$64.6 \pm 13.24$} & \multicolumn{2}{|c|}{$46.0 \pm 19.26$} & 0.058 \\
\hline
\end{tabular}


Table (3A): Mean, SD of studied groups as regards studied parameters.

\begin{tabular}{llllll}
\hline & \multicolumn{5}{c}{ Group } \\
\cline { 2 - 6 } & Benign & Calcular OJ & $\begin{array}{c}\text { Malignant } \\
\text { distal }\end{array}$ & $\begin{array}{c}\text { Malignant } \\
\text { proximal }\end{array}$ & Control \\
\hline Red cell Distribution Width (RDW) \% & $11.81 \pm 1.64$ & $12.09 \pm 1.45$ & $12.2 \pm 1.89$ & $13.02 \pm 3.2$ & $13.59 \pm 2.7$ \\
Mean Platelet Volume (MPV) & $8.4 \pm 1.22$ & $8.46 \pm 0.81$ & $9.02 \pm 0.94$ & $8.28 \pm 0.39$ & $7.95 \pm 0.77$ \\
Plateletcrit (PCT) \% & $24.87 \pm 7.69$ & $23.21 \pm 6.72$ & $22.98 \pm 2.38$ & $25.52 \pm 7.45$ & $26.35 \pm 3.88$ \\
Platelet Distribution Width (PDW) \% & $14.43 \pm 4.28$ & $14.71 \pm 2.65$ & $17.02 \pm 2.38$ & $15.06 \pm 2.08$ & $13.64 \pm 2.02$ \\
Nutrophil/Lymphocyte Ratio (N/L Ratio) & $4.04 \pm 3.91$ & $3.01 \pm 2.81$ & $3.29 \pm 2.46$ & $2.22 \pm 0.31$ & $1.98 \pm 0.49$ \\
Platelet/Lymphocyte Ratio (P/L Ratio) & $184.05 \pm 84.85$ & $178.61 \pm 68.96$ & $134.89 \pm 43.29$ & $190.72 \pm 68.51$ & $151.18 \pm 31.46$ \\
\hline
\end{tabular}

Table (3B): Comparing between studied groups as regards studied parameters.

\begin{tabular}{|c|c|c|c|c|c|c|c|c|c|c|c|}
\hline & $p$-value & $p_{1}$ & $p_{2}$ & $p_{3}$ & $p_{4}$ & $p_{5}$ & $p_{6}$ & $p_{7}$ & $p_{8}$ & $p_{9}$ & $p_{10}$ \\
\hline Red cell Distribution Width (RDW) \% & 0.317 & 0.765 & 0.737 & 0.321 & 0.086 & 0.905 & 0.367 & 0.065 & 0.512 & 0.196 & 0.614 \\
\hline Mean platelet volume (MPV) & 0.216 & 0.874 & 0.203 & 0.812 & 0.293 & 0.171 & 0.677 & 0.132 & 0.164 & $0.020^{*}$ & 0.486 \\
\hline Plateletcrit (PCT) \% & 0.679 & 0.560 & 0.592 & 0.859 & 0.637 & 0.938 & 0.450 & 0.190 & 0.492 & 0.286 & 0.803 \\
\hline Platelet Distribution Width (PDW) \% & 0.217 & 0.832 & 0.106 & 0.704 & 0.573 & 0.077 & 0.797 & 0.324 & 0.239 & $0.020^{*}$ & 0.344 \\
\hline Nutrophil/Lymphocyte Ratio (N/L Ratio) & 0.514 & 0.363 & 0.597 & 0.223 & 0.104 & 0.812 & 0.537 & 0.306 & 0.484 & 0.318 & 0.865 \\
\hline Platelet/Lymphocyte Ratio (P/L Ratio) & 0.416 & 0.846 & 0.167 & 0.857 & 0.295 & 0.145 & 0.703 & 0.270 & 0.150 & 0.618 & 0.257 \\
\hline $\begin{array}{ll}p \text {-value : Comparison between all groups. } \\
p_{1} & : \text { Comparison between Benign and Calc } \\
p_{2} & : \text { Comparison between Benign and Mal } \\
p_{3} & : \text { Comparison between Benign and Mal } \\
p_{4} & : \text { Comparison between Benign and Cont } \\
p_{5} & : \text { Comparison between Calcular OJ and } \\
p_{6} & : \text { Comparison between Calcular OJ and }\end{array}$ & $\begin{array}{l}\text { cular OJ. } \\
\text { lignant Dist } \\
\text { lignant Prox } \\
\text { trol. } \\
\text { 1 Malignant } \\
\text { Malignant }\end{array}$ & $\begin{array}{l}\text { al. } \\
\text { ximal. } \\
\text { Distal. } \\
\text { Proxima }\end{array}$ & $\begin{array}{l}p_{8} \\
p_{9} \\
p_{1} \\
* *\end{array}$ & $\begin{array}{l}\text { : Com } \\
\text { : Com } \\
10: \text { Com } \\
: \text { Stati } \\
\text { : Stati }\end{array}$ & $\begin{array}{l}\text { parison } \\
\text { parison } \\
\text { stically } \\
\text { stically }\end{array}$ & $\begin{array}{l}\text { etweer } \\
\text { etweer } \\
\text { ignific } \\
\text { ighly s }\end{array}$ & $\begin{array}{l}\text { Mallgna } \\
\text { Maligna } \\
\text { Maligna } \\
\text { t differe } \\
\text { ynificant }\end{array}$ & $\begin{array}{l}\text { Distal } \\
\text { nce }(p<0 \\
\text { differen }\end{array}$ & $\begin{array}{l}\text { and Mal } \\
\text { and Cont } \\
\text { nal and C } \\
0.05) \text {. } \\
\text { ce }(p<0.0\end{array}$ & $\begin{array}{l}\text { lignant } \mathrm{P} \\
\text { trol. } \\
\text { Control. }\end{array}$ & mal. \\
\hline
\end{tabular}

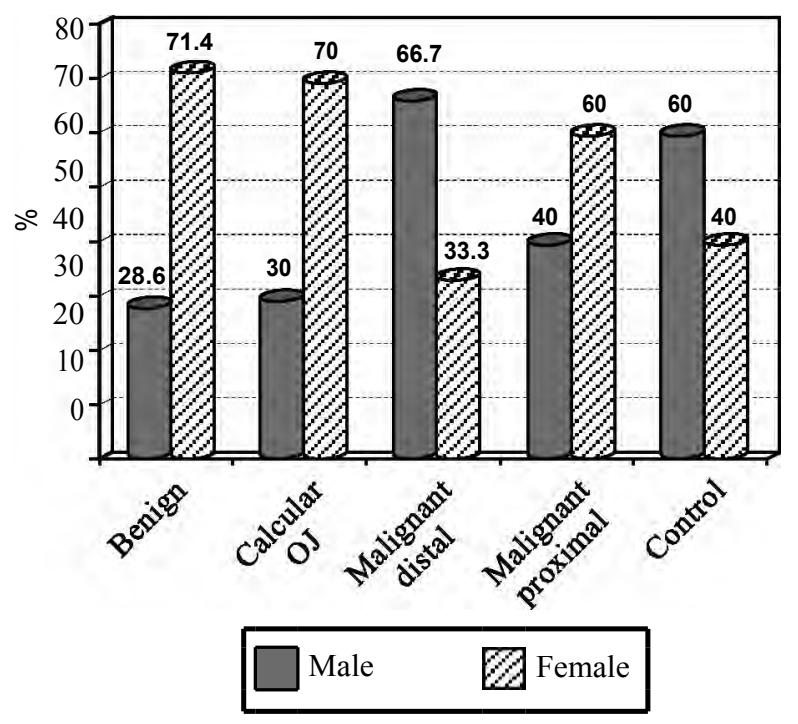

Fig. (1): Comparison between studied groups as regard patient's sex showing no significant differences.

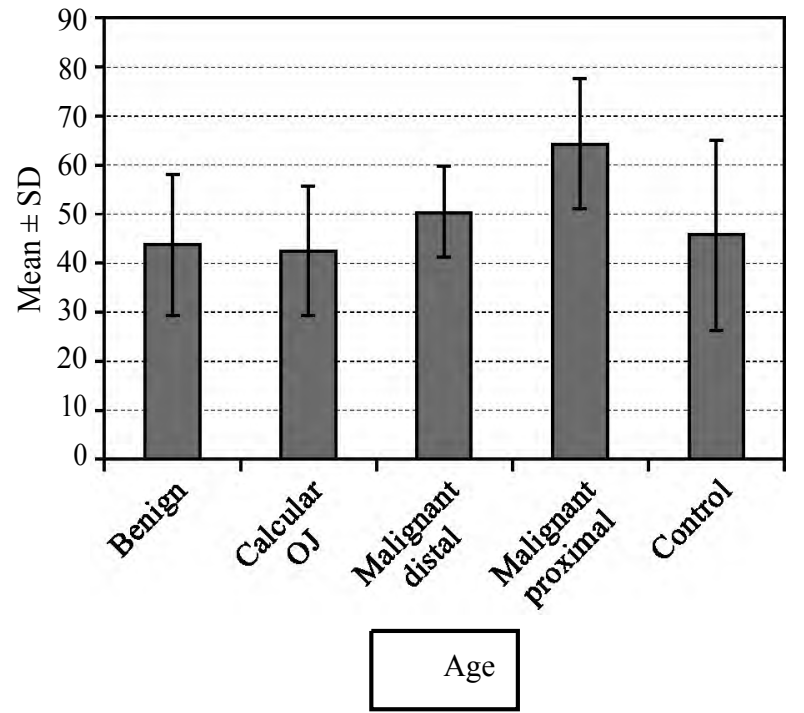

Fig. (2): Comparison between studied groups as regard patient's age showing no significant differences. 


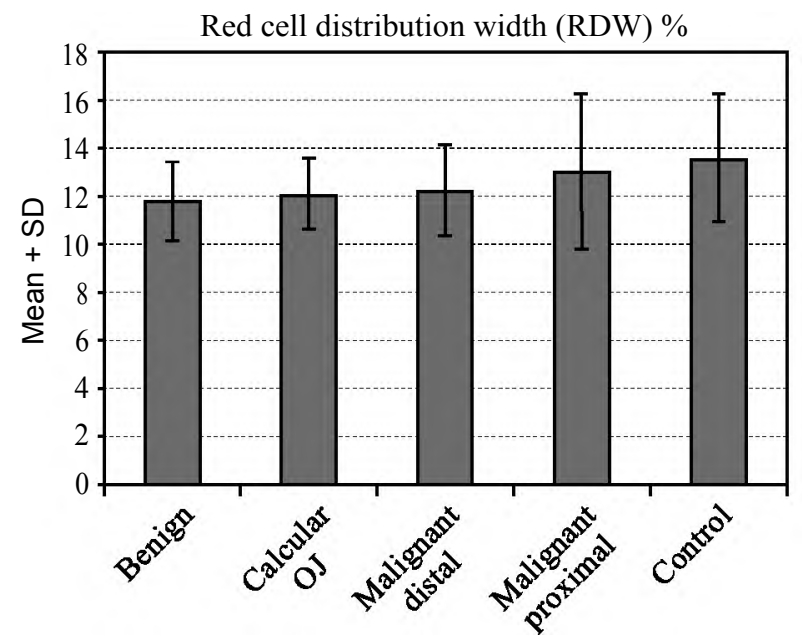

Fig. (3): Showing no significant differences between studied groups as regard RDW.

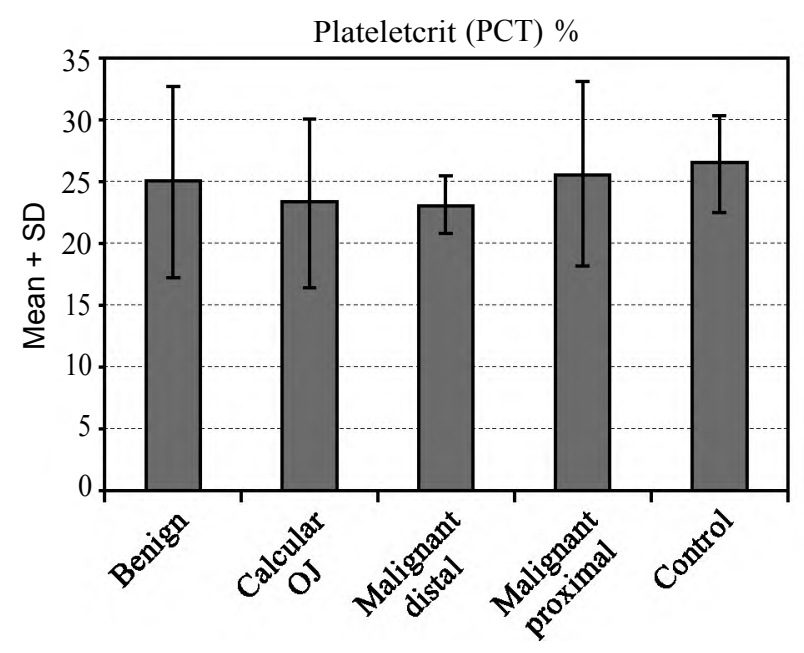

Fig. (5): Showing no significant differences between studied groups as regard PCT.

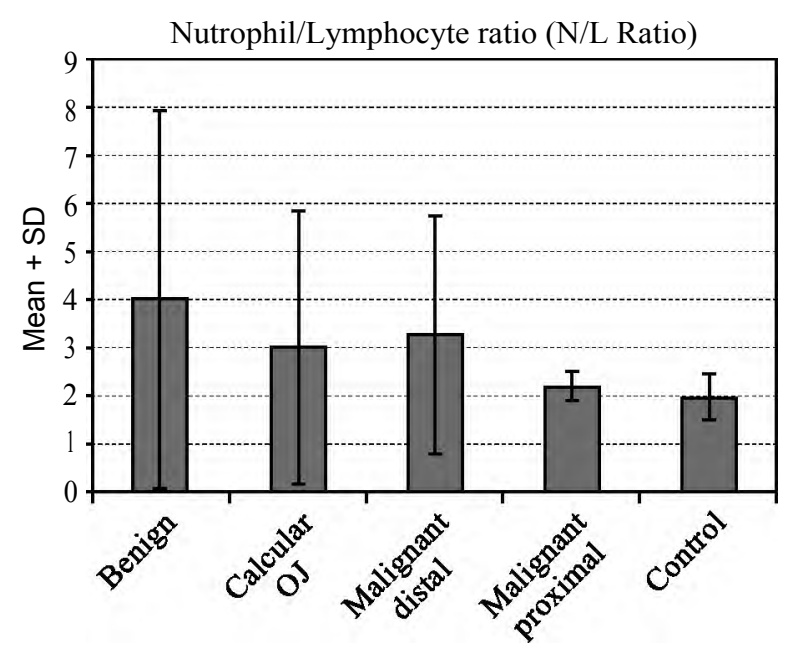

Fig. (7): Showing no significant differences between studied groups as regards NLR.

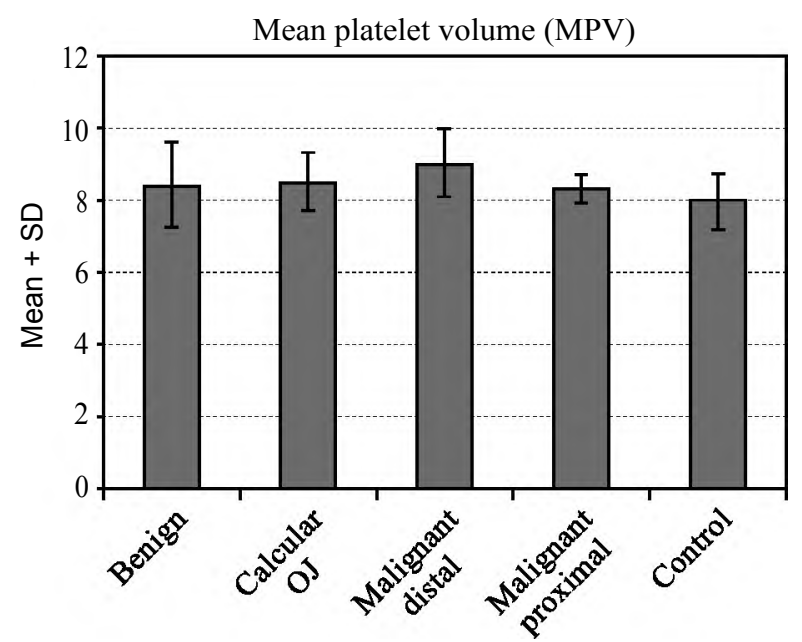

Fig. (4): Showing significant elevation of MPV in malignant distal group than control.

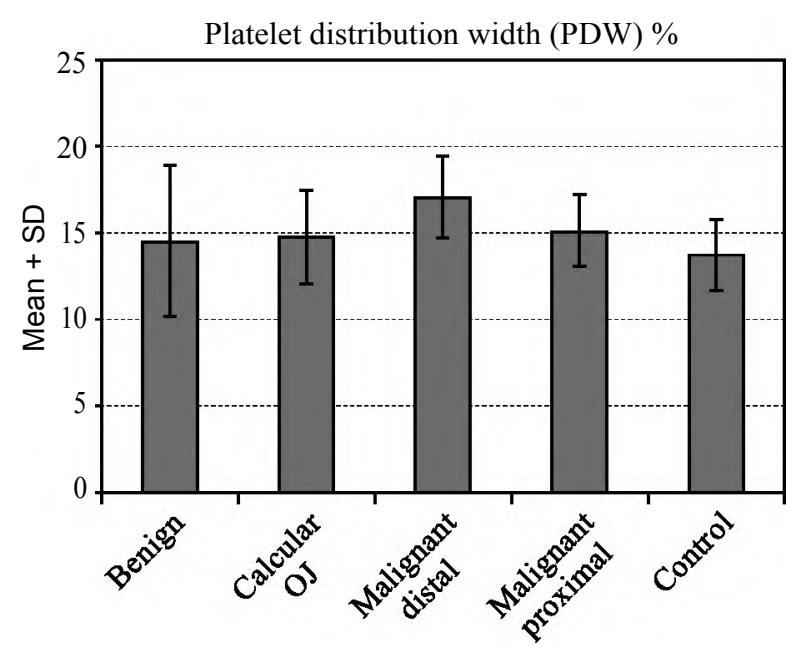

Fig. (6): Showing significant elevation of PDW in malignant distal group than control.

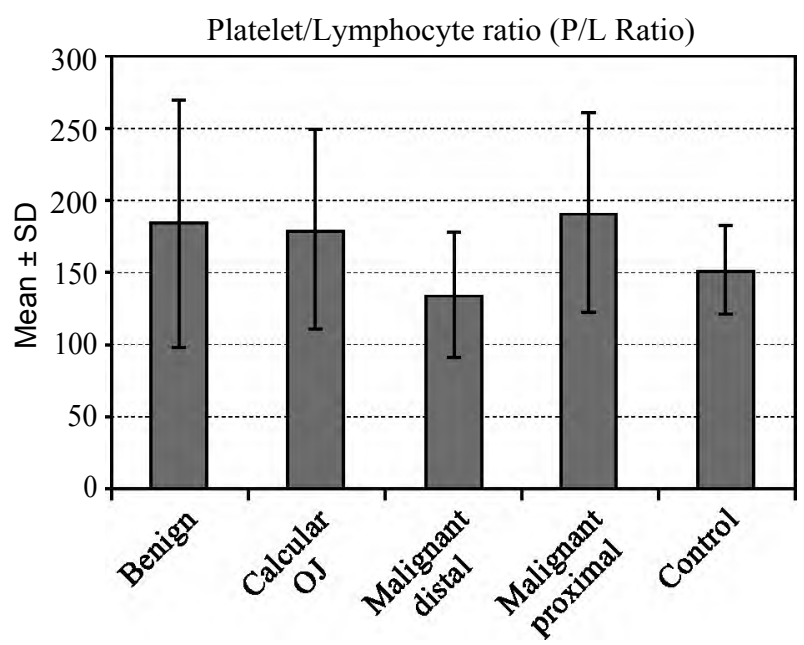

Fig. (8): Showing no significant differences between studied groups as regards PLR. 


\section{Discussion}

The present study is a trial to find a noninvasive, available less expensive method as red blood cells and platelet indices to aid in predicting the cause of extrahepatic cholestasis.

As regard the used $\mathrm{CBC}$ parameters in the present study, several studies for correlation with different diseases.

Buyukkaya, et al., [14] reported that RDW is elevated in non-dipping BP both in normotensive and hypertensive subjects, which may be related with increased inflammatory state. While this study show that RDW has no value in predicting the etiology of extrahepatic cholestasis. Sun, et al., 2016 [15] in a study included 136 patients with a mean follow-up duration of 32 months reported that patients with high RDW levels (>14.8) showed significantly higher all-cause mortality than patients with low RDW levels $(<14.8, p<0.001)$. So RDW could be an additive predictor for all-cause mortality in patients on peritoneal dialysis. Also Nishiyama, et al., 2016 [16] demonstrated that RDW was significantly related to peak $\mathrm{VO}_{2}$ in patients with CAD.

There is insignificant differences in MPV levels between different etiologies of extrahepatic cholestasis while it is significantly increased in malignant distal extrahepatic cholestasis than cases without hyperbilirubinemia in the present study. MPV and especially PDW increase during platelet activation, as depicted by automated hematology analyzers. PDW seems to be a more specific indicator of platelet activation than MPV, since it was not elevated during single platelet distention caused by platelet swelling. The combined use of MPV and PDW could predict activation of coagulation more efficiently [17]. Wang, et al., [18] study showed PDW was higher in the COPD patients with PE $(p=0.007)$. A higher PDW had a significantly increased risk of PE than a lower PDW. While Ren, et al., [19] study could not identify any associations between or PDW and thyroid function. Our study demonstrates that PDW shows no significant differences between different etiologies while it was significantly elevated in malignant distal extrahepatic cholestasis than cases without hyperbilirubinemia. The value of PCT appears additive to conventional expensive methods commonly used in CSX prediction. The mean PCT value of the CSX group was significantly higher than that of the control group ( $p 0.22 \pm 0.06$ vs. $0.19 \pm 0.04$; respectively, $p=0.03)$. Higher PCT was found to be associated with the presence of CSX in patients with normal coronary arteries by multivariate logistic regression analysis (Oylumlu, et al., 2015) [20]. Many cofactors may lead to changes in platelet volume and PCT. But our study shows that PCT has no significant role in discrimination between types of extrahepatic cholestasis.

While Platelet-to-Lymphocyte Ratio (PLR), can predict adverse outcomes in CVD and was investigated as an inflammatory marker [21] it has no role in predicting the etiology of extrahepatic cholestasis according to our results.

Our study does not found significant variations in NLR in different studied groups.

To the best of our knowledge no studies had been done to evaluate CBC parameters in extrahepatic cholestasis.

Several limitations were noted in the current study. First, this study analyzed a single institution experience and may only provide guiding significance in patients with recurrent MOJ. The prognostic values of these inflammatory-related markers or other markers should be investigated in the future study.

\section{Conclusion:}

Our study demonstrate that the six parameters of the complete blood pictures namely RDW, MPV, PDW, PCT, N/L ratio, $\mathrm{P} / \mathrm{L}$ ratio have no significant role in predicting the etiology of extrahepatic cholestasis.

But MPV and PDW show significant elevation distal malignant extrahepatic cholestasis than cases without hyperbilirubinemia.

\section{References}

1- KHURRAM M., DURRANI A.A., HASAN Z., BUTT A.U.A. and ASHFAQ S.: Endoscopic retrograde cholangiopancreatographic evaluation of patients with obstructive jaundice. J. Coll. Physicians. Surg. Pak., Jun., 13 (6): 325-8, 2003.

2- RÂMBOIU S., GHITĂ F., NICOLI R.E. and GEORGESCU I.: The role of biliodigestive derivations in the treatment of choledocholithiasis. Curr. Health Sci. J., Oct., 37 (4): 181-4, 2011.

3- ZORRÓN PU L., De MOURA E.G., BERNARDO W.M., BARACAT F.I., MENDONÇA E.Q., KONDO A., LUZ G.O., FURUYA JÚNIOR C.K. and ARTIFON E.L.: Endoscopic stenting for inoperable malignant biliary obstruction: A systematic review and meta-analysis. World J. Gastroenterol., Dec. 21, 21 (47): 13374-85, 2015. 
4- SINGH A., GELRUD A. and AGARWAL B.: Biliary strictures: Diagnostic considerations and approach. Gastroenterol. Rep. (Oxf.), 3: 22-31, 2015.

5- DADHWAL U.S. and KUMAR V.: Benign bile duct strictures. Med. J. Armed. Forces India., Jul., 68 (3): 299$303,2012$.

6- SOFI A.A., JAVID G., ZARGAR S., NAWRAS A. and SHARMA M.: Comparative evaluation of ERCP and endosonography in the diagnosis of extrahepatic biliary obstruction and a suggested algorithm. Turk. J. Gastroenterol., Apr., 23 (2): 135-40, 2012.

7- OZKALEMKAS F., ALI R., OZKOCAMAN V., et al.: The bone marrow aspirate and biopsy in the diagnosis of unsuspected nonhematologic malignancy: A clinical study of 19 cases. B.M.C. Cancer, 5: 144, 2005.

8- GREER J.P., FOERSTER J., LUKENS J.N., RODGERS G.M., PARASKEVAS F. and GLADER B.: Wintrobe's Clinical Hematology. Wolters Kluwer: Lippincott Williams \&Wilkins, 2003.

9- LEADER A., PEREG D. and LISHNER M.: Are platelet volume indices of clinical use? A multidisciplinary review. Ann. Med., Dec., 44 (8): 805-16, 2012.

10-ZHANG Z., XU X., NI H. and DENG H.: Platelet indices are novel predictors of hospital mortality in intensive care unit patients. J. Crit. Care, 29: 885.e1-6, 2014.

11-AVANZAS P., QUILES J., LÓPEZ D.E. SÁ E., SÁNCHEZ A., RUBIO R., GARCÍA E. and LÓPEZ-SENDÓN J.L.: Neutrophil count and infarct size in patients with acute myocardial infarction. Int. J. Cardiol., 97: 155-6, 2004.

12- OMMEN S.R., HODGE D.O., RODEHEFFER R.J., MCGREGOR C.G., THOMSON S.P. and GIBBONS R.J.: Predictive power of the relative lymphocyte concentration in patients with advanced heart failure. Circulation, 97: 19-22, 1998.

13- SUNBUL M., GERIN F., DURMUS E., KIVRAK T., SARI I., TIGEN K. and CINCIN A.: Neutrophil to lymphocyte and platelet to lymphocyte ratio in patients with dipper versus non-dipper hypertension. Clin. Exp. Hyper tens, 36 (4): 217-21, 2014.

14- BUYUKKAYA E., ERAYMAN A., KARAKAS E., BUGRA NACAR A., KURT M., BUYUKKAYA S., BURAK
AKCAY A. and SEN N.: Relation of red cell distribution width with dipper and non-dipper hypertension. Med. Glas. (Zenica), Aug. 1, 13 (2): 75-81, 2016.

15- SUN I.O., CHUNG B.H., YOON H.J., KIM J.H., CHOI B.S., PARK C.W., KIM Y.S., YANG C.W. and LEE K.Y.: Clinical significance of red blood cell distribution width in the prediction of mortality in patients on peritoneal dialysis. Kidney Res. Clin. Pract., Jun., 35 (2): 114-8, 2016.

16- NISHIYAMA Y., NIIYAMA H., HARADA H., KATOU A., YOSHIDA N. and IKEDA H.: Effect of Exercise Training on Red Blood Cell Distribution Width as a Marker of Impaired Exercise Tolerance in Patients With Coronary Artery Disease. Int. Heart J., Sep. 28, 57 (5): 553-7, 2016.

17- VAGDATLI E., GOUNARI E., LAZARIDOU E., KATSIBOURLIA E., TSIKOPOULOU F. and LABRIANOU I.: Platelet distribution width: A simple, practical and specific marker of activation of coagulation. Hippokratia, Jan., 14 (1): 28-32, 2010.

18- WANG M., ZHANG J., JI Q., YANG Q., ZHAO F., LI W., CHANG H.T. and XIE X.: Evaluation of platelet distribution width in chronic obstructive pulmonary disease patients with pulmonary embolism. Biomark. Med., Jun., 10 (6): 587-96, 2016.

19- REN X., MENG Z., LIU M., ZHU M., HE Q., ZHANG Q., LIU L., SONG K., JIA Q., JIA Q., LI X., TAN J., ZHENG W., WANG R., LIU N. and HU T.: No associations exist between mean platelet volume or platelet distribution width and thyroid function in Chinese. Medicine (Baltimore), Oct., 95 (40): e4573: 1-8, 2016.

20- OYLUMLU M., OYLUMLU M., YUKSEL M., DOGAN A., CAKICI M., OZGEYIK M., YILDIZ A., KILIT C. and AMASYALI B.: The usefulness of plateletcrit to predict cardiac syndrome $\mathrm{X}$ in patients with normal coronary angiogram. Postepy Kardiol Interwencyjnej, 11 (3): 197-201, 2015.

21- GARY T., PICHLER M., BELAJ K., HAFNER F., GERGER A., FROEHLICH H., ELLER P., RIEF P., HACKL G., PILGER E. and BRODMANN M.: Platelet-tolymphocyte ratio: A novel marker for critical limb ischemia in peripheral arterial occlusive disease patients. PLoS One., Jul. 2, 8 (7): e67688, 2013. 


\section{آهمية مؤشرات صورة الدم الكاملة

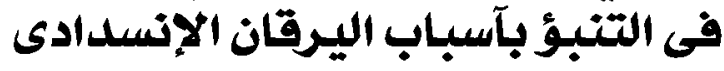

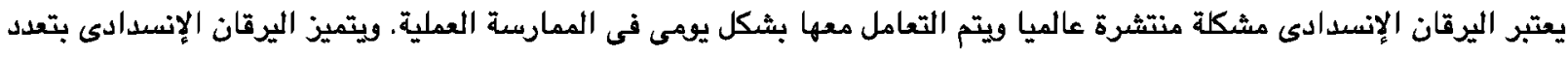

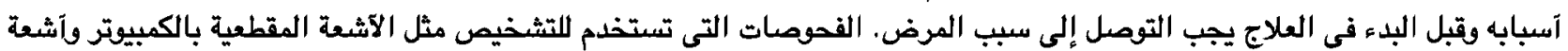

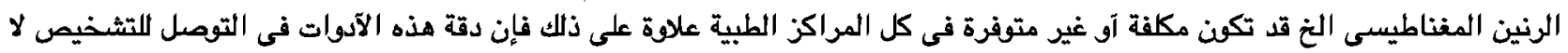
تصل إلى . 1.\%

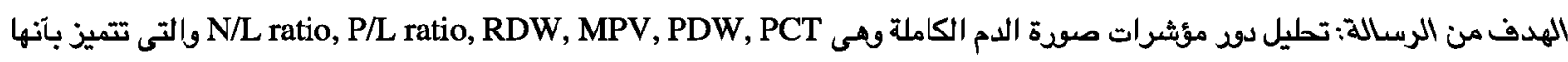

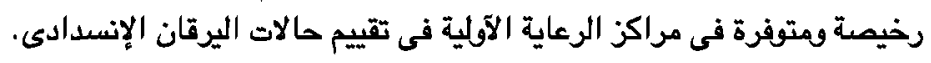

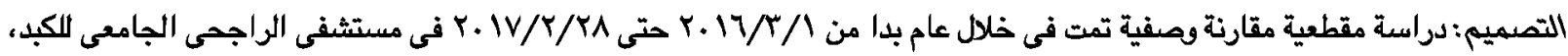

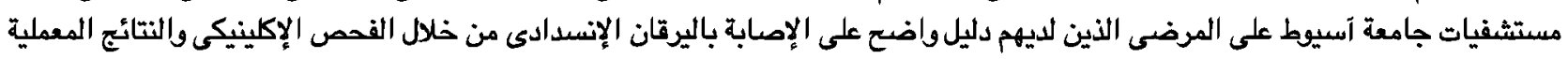
والموجات فوق الصوتيّة على البطن.

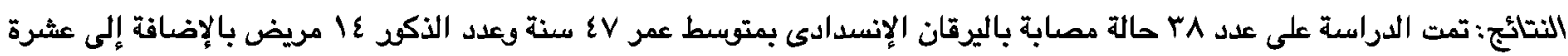

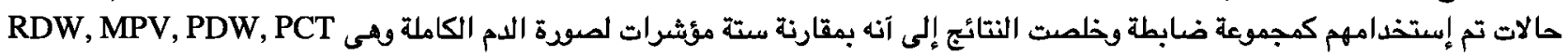

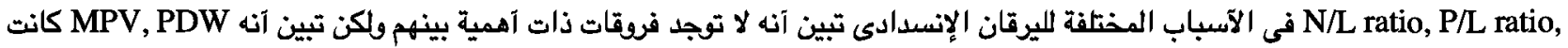

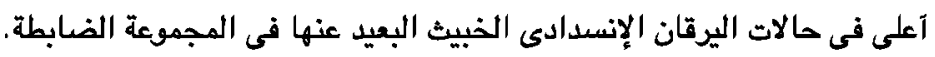

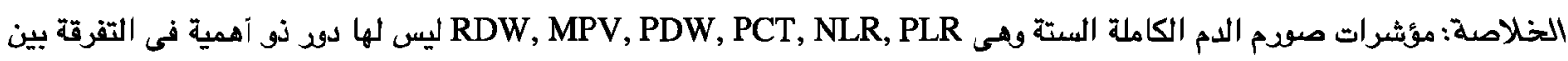
الآسباب المختلفة لليرقان الإنسدادى. ولكن MPV, PDW كانت آعلى فى حالات اليرقان الإنسدادى الضبيث البعيد عنها فى المجموعة الضابطة.

$$
\text { التوصيات: دراسات آخرى على عدد آكبر من المرضى. }
$$

